\title{
Problematika Kuliah Daring Mahasiswa PAI Saat Pandemi Covid-19
}

\author{
Mia Safitri $^{1^{*}}$, Dzulfikar Akbar Romadlon ${ }^{2}$ \\ ${ }^{1,2}$ Universitas Muhammadiyah Sidoarjo, Indonesia
}

\begin{abstract}
Abstrak: Penelitian ini bertujuan untuk mengetahui tentang permasalahan yang dihadapi ketika perkuliahan daring. Penelitian ini menggunakan metode penelitian kualitatif. Pengumpulan data menggunakan survei. Instrumen penelitian berupa angket (google form). Subyek penelitian ini adalah mahasiswa prodi PAI Universitas Muhammadiyah Sidoarjo. Pendataan tentang permasalahan yang dihadapi oleh mahasiswa bertujuan sebagai bahan perbaikan perkuliahan daring jika diperpanjang kembali. Dari data yang didapatkan dari penelitian ini terkait permasalahan yang dihadapi mahasiswa antara lain yaitu terkait kuota internet yang terbatas, jaringan internet, kurang memahami materi yang disampaikan oleh dosen, tugas kuliah menumpuk dan deadline pengumpulan berdekatan. Adapun permasalahan yang perlu dilakukan perbaikan terhadap perkuliahan daring saat ini menurut mahasiswa yaitu penggunaan metode dan media perkuliahan yang digunakan dosen.
\end{abstract}

Kata Kunci: kuliah daring, pandemi Covid-19, mahasiswa

\begin{abstract}
This study aims to find out about the problems faced when lecturing online. This study used qualitative research methods. Data collection using surveys. The research instrument is a questionnaire (google form). The subjects of this study were students of PAI study program, Muhammadiyah University of Sidoarjo. Data collection on the problems faced by students aims to improve online lectures if they are extended again. From the data obtained from this study related to the problems faced by students, among others, related to limited internet quotas, internet networks, lack of understanding of the material presented by lecturers, stacking lecture assignments and close collection deadlines. According to students, the problems that need to be improved on online lectures are the use of lecture methods and media used by lecturers.
\end{abstract}

Keywords: online lectures, Covid-19 pandemic, students

\section{Pendahuluan}

Saat ini dapat kita rasakan bahwa semua negara-negara di dunia telah dilanda oleh virus yang sangat berbahaya dan penyebarannya sangat cepat yaitu Covid-19 seperti halnya Amerika Serikat dengan jumlah kasus 39.664.814, India 32.737.569 kasus, Brazil 20.741.815 kasus, Rusia 6.882.827 kasus, dan lain sebagainya, termasuk Indonesia sendiri yaitu mencapai 4.079.267 kasus.
Kondisi pandemi Covid-19 yang terjadi saat ini memaksa kita untuk melakukan setiap kegiatan di rumah. Oleh karena itu kegiatan yang bersifat mengumpulkan kerumunan atau orang banyak terpaksa dihentikan untuk sementara hingga pada batas waktu yang belum diketahui, tidak hanya itu kegiatan yang dilakukan secara tatap muka atau offline juga dihentikan ataupun diistirahatkan, termasuk halnya kegiatan pembelajaran dalam dunia pendidikan (Harapani, 2020). Untuk itu

Corresponding Author: Mia Safitri (miaasafitri11@gmail.com). Universitas Muhammadiyah Sidoarjo, Indonesia

p-ISSN 1412-1697; e-ISSN 2477-3816

http://jurnal.radenfatah.ac.id/index.php/intizar 
Kementerian Pendidikan dan Kebudayaan Bapak Nadiem Makarim membuat kebijakan yang dilengkapi dengan turunnya surat edaran nomer 4 Tahun 2020 tentang pelaksanaan kebijakan pendidikan dalam masa darurat penyebaran Covid19 yang mengharuskan dunia pendidikan menggunakan sistem dalam jaringan (Daring/jarak jauh). Hal tersebut bertujuan untuk menekan mata rantai penyebaran Covid-19 di sekolah dasar maupun perguruan tinggi. Istilah daring merupakan sebuah akronim atau kepanjangan dari "dalam jaringan“. Pembelajaran daring merupakan salah satu cara atau metode pembelajaran online yang dilakukan dengan menggubungkan jaringan internet (Mulyana et al., 2020).

Model pembelajaran daring sendiri merupakan sebuah kerangka konseptual berupa prosedur yang tersusun secara sistematis dalam mengorganisasikan pengalaman belajar yang akan digunakan dalam proses pembelajaran yang memanfaatkan jaringan internet sehingga suasana pembelajaran menjadi menarik dan tujuan pembelajaran dapat tercapai di dalamnya (Berta Dinata, 2020). Salah satu cara yang dilakukan untuk memudahkan mahasiswa dalam mengakses materi pembelajaran yang telah diberikan oleh dosen dapat melalui pemanfaatan sistem pembelajaran daring yang merupakan salah satu upaya yang dapat dilakukan agar bisa saling berkomunikasi dan berdiskusi secara online (Anugrahana, 2020). Tidak hanya itu pembelajaran daring juga dapat menghubungkan peserta didik maupun mahasiswa dengan sumber belajar lainnya seperti, database, pakar atau instruktur, dan perpustakaan yang secara fisik terpisah atau bahkan berjauhan namun dapat saling berkomunikasi dan berinteraksi secara langsung maupun tidak langsung (Sadikin \& Hamidah, 2020).

Pandemi Covid-19 yang terjadi mengharuskan pembelajaran menjadi daring tidak terkecuali bagi mahasiswa, dimana sebelum masa pandemi seperti saat ini hari-hari kuliah dijalani secara konvensional. Perkuliahan secara konvensional dirasa lebih mudah dan lebih efektif jika dibandingkan dengan perkuliahan secara daring. perkuliahan daring, sering kali terjadi banyak kendala yang dihadapi, seperti banyaknya kuota yang dihabiskan untuk perkuliahan. Penelitian terdahulu yang mengkaji permasalahan tersebut juga menunjukkan bahwa masalah yang dihadapi mahasiswa selama pembelajaran daring antara lain koneksi internet, media daring sering eror dan keterbatasan kuota internet (Widodo \& Nursaptini, 2004). Oleh karena itu keefektifan perkuliahan secara konvensional dapat dikatakan lebih tinggi dibandingkan secara daring, serta kebutuhan perkuliahan daring lebih tinggi dibandingkan dengan kuliah secara konvensional (Wirakesuma Agusta, 2020).

Konsep dari Pembelajaran daring (online) sendiri umumnya memiliki perbedaan yang signifikan jika dibandingkan dengan pembelajaran tatap muka atau konvensional. Pembelajaran daring (online) lebih menitikberatkan pada ketelitian mahasiswa dalam menerima serta mengolah informasi yang telah disajikan oleh guru maupun dosen secara online. Pembelajaran daring (online) umumnya menggunakan E-learning. E-Learning sendiri merupakan suatu sistem pembelajaran dengan menggunakan media Internet, Intranet atau media jaringan komputer lain yang dapat diakses kapanpun dan di manapun, sehingga dapat mengatasi kendala ruang dan waktu. E-Learning dapat dikatakan sebagai solusi alternatif atas sebagian besar permasalahan pendidikan yang ada di Indonesia saat ini, yang memiliki fungsi yang dapat disesuaikan dengan kebutuhan, baik sebagai substitusi (pengganti), suplemen (tambahan), ataupun komplemen (pelengkap), atas kegiatan pembelajaran di dalam kelas (Ulfatin, 2008). 
Proses pembelajaran secara daring (online) yang dilewati saat ini banyak sekali hambatan dan rintangan yang sedang dirasakan oleh banyak pihak (Dzalila et al., 2020). Di antaranya yaitu tantangan bagi peserta didik atau mahasiswa serta menjadi tantangan yang besar bagi guru maupun dosen. Tugas mahasiswa disini harus mengerjakan tugas yang lumayan sulit dan deadline bersamaan serta tantangan tersendiri bagi dosen adalah harus mengoreksi satu persatu tugas yang telah dikerjakan oleh mahasiswanya dan umumnya setiap tenaga pengajar/dosen dalam institusi perguruan tinggi dapat memiliki pertimbangan sendiri untuk memilih model pembelajaran mana yang dianggap paling cocok untuk diselenggarakan pada pembelajaran mahasiswa agar mahasiswa tidak mengalami kejenuhan saat perkuliahan daring (Zhafira et al., 2020). Hal tersebut diharapkan agar semua pihak yang terlibat dalam pembelajaran daring harus dituntut untuk selalu berupaya memaksimalkan proses pmbelajaran jarak jauh (PJJ) agar tidak sampai terjadi kelumpuhan dalam dunia pendidikan itu sendiri (Alvianto, 2020).

Adapun alternatif atau solusi yang diberikan untuk melakukan pembelajaran daring (online) yakni dengan menggunakan media online yang ada saat ini. Adapun media yang lainnya yang dapat digunakan sebagai penunjang dalam pembelajaran daring antara lain yaitu Google Classroom, Whatsapp, Quipper, Microsoft, Google Meet, Zoom Meeting dan Youtube (Hasanah et al., 2020). Terdapat penelitian (Anggraeni et al., 2020) yang mengatakan bahwa melalui sarana tersebut, baik dosen maupun mahasiswa dapat menciptakan pemikiran dan konten kreativitas untuk pembelajaran, misalnya dosen memberikan materi menggunakan konten video kreatif yang bersifat persuasif, sehingga mahasiswa menjadi lebih tertarik mengikuti pembelajaran.
Sedangkan metode pembelajaran yang dilakukan saat daring seperti ini kebanyakan dari mulai tingkat dasar hingga perguruan tinggi menggunakan sistem penugasan hingga problem based learning untuk meningkatkan pembelajaran. Pembelajaran merupakan hal yang sangat inti dari proses pendidikan. Kualitas pendidikan yang baik dapat dilihat dari kualitas pembelajaran tersebut. Untuk meningkatan kualitas pendidikan dapat dilakukan dengan cara meningkatan kualitas pembelajaran yang dilakukan. Menurut (Argaheni, 2020) pendidikan dengan jarak jauh memiliki tujuan agar mutu pendidikan meningkatkan dan relevansi pendidikan serta meningkatkan pemerataan akses dan perluasan pendidikan. Pendidikan jarak jauh yang diselenggarakan dengan penjaminan kualitas yang baik dan sesuai dengan kebutuhan pemangku kepentingan akan menjadi salah satu mekanisme perluasan akses pendidikan tinggi.

Penelitian ini bertujuan untuk melihat secara objektif apa saja problematika atau permasalahan yang dihadapi oleh mahasiswa PAI terhadap perkuliahan yang dilakukan secara daring di Universitas Muhammadiyah Sidoarjo. Problematika perkuliahan daring akan diuraikan berdasarkan segi respon mahasiswa. Pengumpulan data tentang permasalahan yang dihadapi oleh mahasiswa PAI pada perkuliahan daring di Universitas Muhammadiyah Sidoarjo diperoleh melalui google form. Hasil dari evaluasi yang telah dilakukan diharapkan dapat digunakan untuk memperbaiki proses pembelajaran daring untuk kedepannya. Apalagi saat ini masih dalam masa pandemi Covid19, sehingga perlu adanya perbaikan dalam pembelajaran daring sehingga proses pembelajaran menjadi lebih efektif dan dapat dikatakan efisien. 


\section{Metode}

Metode yang digunakan dalam penelitian ini adalah kualitatif dengan menggunakan teknik survei. Penelitian kualitatif bermaksud untuk memahami fenomena tentang apa yang dialami oleh subjek penelitian yang berupa perilaku, persepsi, motivasi, tindakan, dan lain-lain, secara holistik dan dengan cara deskripsi dalam bentuk kata-kata dan bahasa pada suatu konteks khusus yang alamiah dengan memanfaatkan berbagai metode alamiah. Subjek dalam penelitian ini adalah mahasiswa Pendidikan Agama Islam (PAI) Universitas Muhammadiyah Sidoarjo. Teknik Pengumpulan data berupa survei yang dilakukan melaui angket atau kuisioner menggunakan google form yang telah di sebar kepada mahasiswa prodi PAI Universitas Muhammadiyah Sidoarjo. Terdapat sebanyak 53 responden yang terlibat dalam penelitian ini. Pengambilan sampel menggunakan metode simple random sampling, yaitu terdiri dari mahasiswa PAI mulai dari semester dua hingga delapan yang memiliki kesempatan sama untuk menjadi responden dalam penelitian ini. Penelitian ini dilaksanakan pada bulan Mei-Juni 2021.

Adapun komponen yang diukur dalam angket atau kuisioner dalam bentuk Google form dituangkan dalam 6 pertanyaan, antara lain 1) Apakah anda mengalami hambatan atau kendala saat mengikuti kuliah daring?, 2) Apa hambatan atau kendala yang anda alami saat mengikuti kuliah daring?, 3) Seberapa baik kualitas penyajian materi kuliah daring baik berupa gambar, ppt, pdf,video, dan lain-lain yang diberikan oleh bapak/ibu dosen?,

4) Apakah anda mampu mengikuti dengan baik terhadap model pembelajaran yang dilakukkan dosen?, 5) Sejauh ini secara keseluruhan seberapa senang anda terhadap perkuliahan daring?, dan 6) Menurut anda apakah yang harus diperbaiki dalam perkuliahan daring ini?.

\section{Hasil Penelitian dan Pembahasan}

Penelitian ini dilaksankan dengan menggunakan google form yang telah di sebar kepada mahasiswa prodi PAI Universitas Muhammadiyah Sidoarjo. Terdapat sebanyak 53 responden yang terlibat dalam penelitian ini. Jumlah pertanyaan yang diberikan sebanyak enam pertanyaan. Untuk pertanyaan pertama yaitu apakah anda mengalami hambatan atau kendala saat mengikuti perkuliahan daring?. Dari pertanyaan tersebut didapatkan jawaban sebagai berikut:

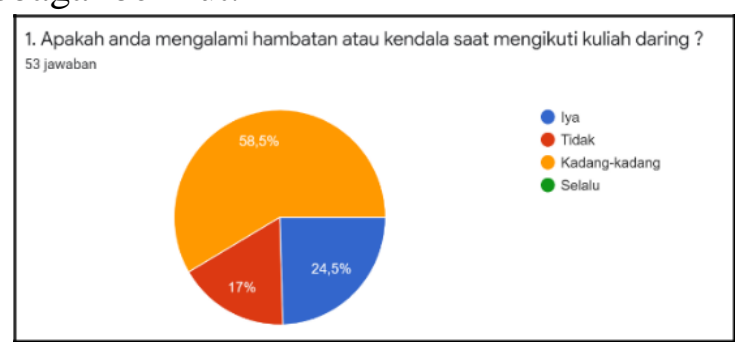

Gambar 1. Kendala perkuliahan daring

Berdasarkan gambar di atas maka dapat diketahui bahwa responden yang kadang-kadang mengalami kesulitan sebanyak 58,5\%. Responden yang mengaku mendapat kesulitan sebanyak 24,5\%. Sedangkan yang menjawab tidak pernah mengalami kesulitan sebanyak 17\%. Dari data di atas menunjukkan bahwa banyak yang menjawab kadang-kadang maka hal tersebut bermakna bahwa kesulitan tersebut ada atau dialami oleh responden dan kesulitan tersebut terjadi tergantung pada letak proses berlangsungnya perkuliahan yang responden terima. Pertanyaan kedua yang diberikan kepada responden yaitu, Apa hambatan atau kendala yang anda alami saat mengikuti kuliah daring? Pertanyaan tersebut bertujuan untuk mengetahui lebih dalam hambatan atau kendala yang dialami responden dan lanjutan dari pertanyaan yang pertama. Berikut merupakan diagram yang menunjukkan jawaban dari responden: 


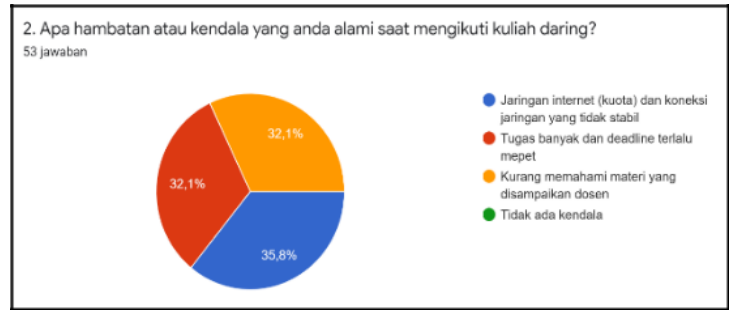

Gambar 2. Jenis hambatan kuliah daring

Tabel 2. Jumlah responden yang mengalami kendala kuliah daring

\begin{tabular}{|c|c|}
\hline Hambatan & Jumlah \\
\hline $\begin{array}{c}\text { Jaringan internet (kuota) } \\
\text { dan koneksi jaringan yang } \\
\text { tidak stabil }\end{array}$ & 19 Responden \\
\hline $\begin{array}{c}\text { Tugas banyak dan deadline } \\
\text { terlalu mepet }\end{array}$ & 17 Responden \\
\hline $\begin{array}{c}\text { Kurang memahami materi } \\
\text { yang disampaikan dosen }\end{array}$ & 17 Responden \\
\hline Total responden & 53 Responden \\
\hline
\end{tabular}

Berdasarkan gambar dan tabel di atas dapat diketahui bahwa hambatan atau kendala saat perkuliahan daring yang dialami oleh responden sangat beragam. Hambatan atau kendala yang utama yang paling banyak dialami yaitu jaringan internet (kuota) dan koneksi jaringan yang tidak stabil. Jumlah responden yang terkendala oleh jaringan internet kuota) dan koneksi jaringan sebanyak 35,8\% atau 19 responden. Sedangkan untuk presentase jumlah responden yang mengalami kendala tugas banyak dan deadline terlalu mepet serta kurang memahami materi yang telah disampaikan oleh dosen mengalami persamaan jawaban yaitu sebanyak 32,1\%. Data tersebut menunjukkan bahwa sebagian besar mahasiswa mengalami kendala saat perkuliahan daring khususnya pada jaringan internet atau kuota, karena saat perkuliahan daring banyak sekali membutuhkan kuota dan jaringan internet untuk mengakses materi perkuliahan yang diberikan oleh dosen. Bahkan hanya terhitung sebagian kecil responden yang tidak pernah mengalami kendala apapun saat perkuliahan daring. Pertanyaan ketiga yang diberikan kepada responden yaitu, Seberapa baik kualitas penyajian materi kuliah daring baik berupa gambar, PPT, PDF, video, dan lain-lain yang diberikan oleh Bapak/Ibu dosen?. Berikut diagram yang menunjukkan jawaban dari responden:

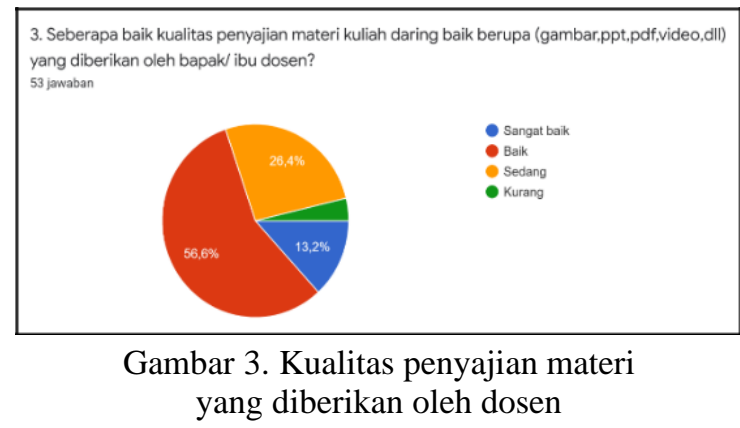

Berdasarkan pada diagram 3 dapat diketahui bahwa responden yang menjawab kualitas penyajian materi kuliah yang diberikan oleh dosen sangat baik berjumlah 13,2\%. Responden yang mengaku bahwa penyajian materi kuliah yang diberikan oleh dosen baik berjumlah 56,6\%. Responden yang menjawab sedang berjumlah $26,4 \%$. Sedangkan yang mengaku kurang dalam penyajian materi yang diberikan oleh dosen sebanyak 3,8\%. Maka dari data tersebut menunjukkan bahwa kualitas penyajian materi kuliah yang diberikan oleh dosen baik berupa gambar, PPT, PDF, video, dan lain-lain. Cukup baik dan tidak terdapat masalah dalam hal tersebut, karena banyak responden yang mengakui bahwa penyajian materi yang diberikan oleh dosen untuk perkuliahan sudah baik. Tetapi hal tersebut masih perlu adanya peningkatan kualitas penyajian materi. Pertanyaan keempat yang diberikan kepada responden adalah Apakah anda mampu mengikuti dengan baik terhadap model pembelajaran yang dilakukan dosen?. Berikut merupakan diagram yang menunjukkan jawaban dari responden : 


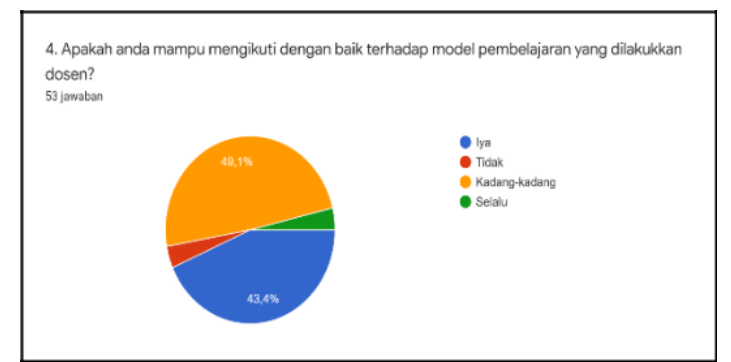

Gambar 4. Kemampuan responden dalam mengikuti pembelajaran daring

Berdasarkan pada diagram di atas maka dapat diketahui bahwa responden yang dapat mengikuti dengan baik pembelajaran yang dilakukan oleh dosen sebanyak 43,4\%. Responden yang mengaku kadang-kadang dapat mengikuti pembelajaran sebanyak $49,1 \%$. Responden yang mengaku tidak dapat mengikuti pembelajaran sebanyak 3,8\%. Sedangkan responden yang dapat mengikuti selalu pembelajaran yang diberikan oleh dosen sebanyak 3,8\%. Maka dari data diatas menunjukkan bahwa jumlah responden yang dapat mengikuti pembelajaran daring dengan baik lebih sedikit dibandingkan dengan responden yang menjawab kadang-kadang dapat mengikuti pembelajaran dengan baik. Pertanyaan kelima yang diberikan kepada responden yaitu, Sejauh ini secara keseluruhan seberapa senang anda terhadap perkuliahan daring?. Berikut merupakan jawaban dari responden dalam bentuk diagram :

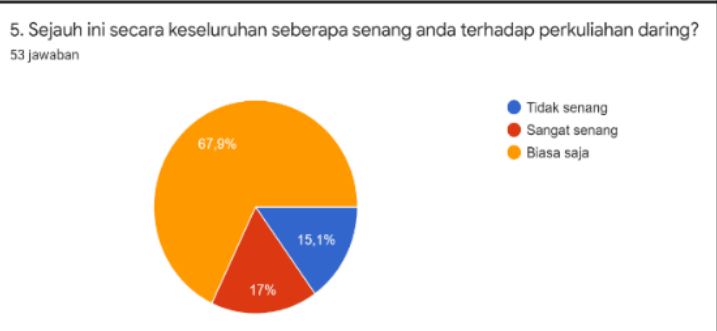

Gambar 5. Tingkat kesenangan perkuliahan daring
Tabel 5. Jumlah responden terhadap kesenangan kuliah daring

\begin{tabular}{|c|c|}
\hline Respon & Jumlah \\
\hline Tidak senang & 8 Responden \\
\hline Sangat senang & 9 Responden \\
\hline Biasa saja & 36 Responden \\
\hline Total responden & 53 Responden \\
\hline
\end{tabular}

Berdasarkan gambar di atas dapat diketahui bahwa tanggapan dari responden yang mengaku biasa saja terkait seberapa senang terhadap perkuliahan daring lebih besar dibandingkan dengan responden yang tidak senang terhadap perkuliahan daring. Hal tersebut terlihat dari jawaban responden yaitu yang mengaku biasa saja terhadap perkuliahan daring sebanyak $67,9 \%$. Responden yang sangat senang terhadap perkuliahan dari sebanyak $17 \%$ dan responden yang tidak senang perkuliahan dari sebanyak $15,1 \%$. Pertanyaan keenam yang diajukan kepada responden yaitu, Menurut anda apakah yang harus diperbaiki dalam perkuliahan daring ini?. Berikut merupakan jawaban dari responden dalam bentuk diagram:

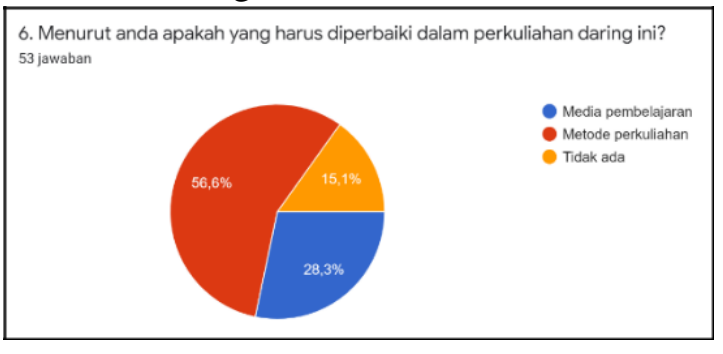

Gambar 6. Perbaikan kuliah daring bagi responden

Berdasarkan diagram di atas dapat diketahui bahwa sebanyak $56,6 \%$ responden menginginkan adanya perbaikan metode perkuliahan yang digunakan oleh dosen saat perkuliahan daring. Metode perkuliahan yang diharapkan oleh responden adalah yang dirasa tidak membosankan. Karena saat perkuliahan daring 
seperti saat ini dosen kurang memberikan pendalaman materi serta sering memberikan penugasan. Aspek kedua yang harus diperbaiki dari perkuliahan daring yaitu media pembelajaran. Sebanyak $28,3 \%$ responden yang mengakui bahwa media pembelajaran saat perkuliahan daring perlu adanya perbaikan. Karena media pembelajaran merupakan alat yang dirasa cukup penting untuk berjalan atau tidaknya suatu pembelajaran. Media pembelajaran yang diharapkan oleh responden dapat mudah diakses dan tidak membutuhkan kuota internet yang banyak.

Berdasarkan penelitian di atas maka dapat diketahui bahwa dalam perkuliahan daring terdapat beberapa masalah yang harus diperbaiki untuk meningkatkan perkuliahan yang lebih efektif dan efisien. Hal ini sesuai dengan hasil penelitian yang telah dilakukan (Rasyida, 2020) yang mengatakan bahwa ada beberapa permasalahan utama yang dihadapi mahasiswa dalam perkuliahan daring diantaranya yaitu jaringan yang tidak stabil, pengeluaran biaya yang lebih besar, banyaknya tugas yang diberilan oleh dosen, sehingga perkuliahan menjadi tidak efektif.

Pembelajaran daring merupakan salah satu pembelajaran yang membutuhkan kesiapan baik dari dosen maupun dari kalangan mahasiswa sendiri. Kesiapan yang dimaksud yaitu seperti, ketersediaan media untuk melaksanakan pembelajaran daring misalnya laptop atau gadget, ketersediaan jaringan internet, dan ketersediaan kuota internet, serta aplikasi penunjang yang digunakan dalam pembelajaran daring yang harus dikuasai oleh mahasiswa (Vonnisye, 2020). Oleh karena itu dengan adanya sistem pembelajaran secara daring ini, terkadang muncul berbagai masalah yang dihadapi oleh mahasiswa maupun dosen. Masalah yang paling sering muncul dialami oleh mahasiswa saat perkuliahan daring yaitu tentang jaringan internet serta sarana pembelajaran daring yang tidak dimiliki oleh semua mahasiswa bahkan jaringan dan kuota internet menjadi kendala yang sangat besar di kalangan mahasiswa yang kurang mampu (Noviantari \& Payadnya, 2021). Terlebih lagi mahasiswa yang berdomisili di luar kota yang sulit untuk mencari jaringan internet, hal tersebut merupakan permasalahan terbesar yang dirasakan. Permasalahan lain selain jaringan internet yaitu kuota internet. Meskipun telah diberikan subsidi kuota oleh Kementrian Pendidikan dan Kebudayaan (Kemendikbud), mahasiswa merasa kurang karena dalam setiap harinya mereka harus mengikuti perkuliahan yang diberikan oleh dosen. Terkadang sehari mereka bisa melakukan perkuliahan daring menggunakan zoom atau meet sekitar 2-3 kali. Oleh karena itu kuota internet merupakan permasalahan yang dirasakan oleh mahasiswa dalam menghadapi perkuliahan dari seperti saat ini. Permasalahan kedua yang dirasakan oleh mahasiswa yaitu tugas yang diberikan oleh dosen terlalu banyak dan deadline pengumpulan berdekatan. Untuk perkuliahan daring seperti saat ini dosen sering memberikan penguatan materi berupa penugasan oleh karena itu tidak salah jika mahasiswa banyak yang mengeluh terkait banyak tugas yang diberikan oleh dosen. Permasalahan yang ketiga yaitu kurang memahami materi yang telah disampaikan oleh dosen. Mahasiswa mengakui bahwa kurang konsentrasi dan kurang memahami materi saat perkuliahan daring. Salah satu penyebab tersebut yaitu keadaan rumah yang kurang kondusif. Terlebih lagi bagi mahasiswa yang harus membantu pekerjaan orang tuanya. Selain itu banyak mahasiswa yang mengeluh karena merasa bosan jika harus berlama-lama menatap layar laptop maupun gedget. Tidak heran jika dalam perkuliahan daring seperti saat ini dapat menurunkan kemampuan akademik mahasiswa serta minat baca yang semakin rendah. 
Berdasarkan paparan diatas maka permasalahan-permasalahan yang terjadi dalam pembelajaran perlu diadakan evaluasi lebih lanjut. Apabila permasalahan tersebut tidak segera diatasi, maka secara tidak langsung akan berdampak pada mahasiswa. Serta tujuan dari pembelajaran dapat dikatakan tidak mencapai apa yang telah direncanakan. Untuk evaluasi yang pertama yaitu perbaikan tentang metode perkuliahan. Mahasiswa berharap agar metode yang dilakukan oleh dosen tidak monoton atau terkesan membosankan karena disetiap harinya dosen memberikan materi berupa PDF atau PPT disertai dengan penugasan tanpa adanya pendalaman materi. Aspek yang kedua yang harus diperbaiki yaitu tentang media pembelajaran. Mahasiswa berharap dengan adanya media pembelajaran yang tidak membutuhkan kuota dan jaringan internet yang banyak mereka dapat leluasa untuk mengikuti perkuliahan tanpa khawatir akan berapa banyak kuota internet yang dihabiskan, serta berharap agar media pembelajaran yang digunakan lebih mudah untuk diakses oleh mahasiswa.

\section{Kesimpulan}

Berdasarkan hasil penelitian dapat diketahui bahwa selama perkuliahan daring terdapat beberapa permasalahan dikalangan mahasiswa, khususnya mahasiswa PAI Universitas Muhammadiyah Sidoarjo. Permasalahan yang dihadapi antara lain yaitu terkait kuota internet yang terbatas, jaringan internet, kurang memahami materi yang disampaikan oleh dosen, tugas kuliah menumpuk dan deadline pengumpulan berdekatan. Adapun permasalahan yang perlu dilakukan evaluasi atau perbaikan terhadap perkuliahan daring saat ini yaitu pengunaan metode perkuliahan dan media perkuliahan yang digunakan oleh dosen. Mahasiswa berharap agar media yang digunakan oleh dosen dalam perkuliahan tidak membutuhkan kuota yang banyak untuk mengaksesnya, serta metode perkuliahahan yang tidak monoton. Maka dari itu disarakan kepada dosen untuk mendesain media maupun metode perkuliahan yang lebih bervariasi agar mahasiwa tidak merasakan kebosanan dalam menerima dan mengikuti dengan baik perkuliahan yang diajarkan. Sehingga diharapkan pembelajaran daring bisa bersifat efektif dan efisien sesuai dengan apa yang diharapkan oleh mahasiswa dan dosen.

\section{Daftar Pustaka}

Alvianto, A. (2020). Daring Mata Kuliah Pendidikan Agama Islam Pada Situasi Pandemi Covid-19. 13(02), 1-16.

Anggraeni, A. W., Angelina, D., \& Dwijayanti, M. (2020). Tanggapan Mahasiswa Terhadap Pembelajaran Daring Di Masa Karantina Covid-19. Humaniora Dan Era Disrupsi, 1(1), 627-638.

Anugrahana, A. (2020). Hambatan, solusi dan harapan: pembelajaran daring selama masa pandemi covid-19 oleh guru sekolah dasar. Scholaria: Jurnal Pendidikan Dan Kebudayaan, 10(3), 282-289.

Argaheni, N. B. (2020). Sistematik Review: Dampak Perkuliahan Daring Saat Pandemi COVID-19 Terhadap Mahasiswa Indonesia. PLACENTUM: Jurnal Ilmiah Kesehatan Dan Aplikasinya, 8(2), 99. https://doi.org/10.20961/placentum.v8i2.430 08

Berta Dinata, K. (2020). Problematika Pembelajaran Daring Mata Kuliah Geometri Transformasi di Masa Pandemi Covid-19. Eksponen, 10(2), 50-58. https://doi.org/10.47637/eksponen.v10i2.296 Dzalila, L., Ananda, A., \& Zuhri, S. (2020). Pengaruh Pembelajaran Daring Pada Masa Pandemi Covid-19 Terhadap Tingkat Pemahaman Belajar Mahasiswa. Jurnal Signal, 8(2), 203. https://doi.org/10.33603/signal.v8i2.3518

Harapani, A. (2020). Pengaruh Kuliah Daring Saat Pandemi Covid-19 Terhadap Kemampuan Mahasiswa.

Hasanah, F. N., Setiawan, T., Studi, P., Agama, P., \& Pekalongan, I. (2020). Pembelajaran daring

Intizar - Vol. 27 No. 2 (2021) 
di masa pandemi covid-19 pada perguruan tinggi keagamaan islam negeri ( studi di IAIN Pekalongan ). Indonesian Journal of Educational Science (IJES), 03(01), 12-23.

Mulyana, M., Rainanto, B. H., Astrini, D., \& Puspitasari, R. (2020). Persepsi Mahasiswa Atas Penggunaan Aplikasi Perkuliahan Daring Saat Wabah Covid-19. JAS-PT (Jurnal Analisis Sistem Pendidikan Tinggi Indonesia), $4(1), \quad 47$. https://doi.org/10.36339/jaspt.v4i1.301

Noviantari, P. S., \& Payadnya, I. P. A. A. (2021). Persepsi Mahasiswa Terhadap Kuliah Daring Pada Masa Pandemi Covid-19. Jurnal Pembelajaran Dan Pengembangan Matematika, Vol. 1, No. 1 (Maret 2021) Program Studi Pendidikan Matematika, Fakultas Keguruan Dan Ilmu Pendidikan, Universitas Mahasaraswati Denpasar, 1(1), $13-22$.

Rasyida, H. (2020). Efektivitas Kuliah Daring Di Tengah Pandemik. Jurnal Edukasi, 1(November), 1-8.

Sadikin, A., \& Hamidah, A. (2020). Pembelajaran Daring di Tengah Wabah Covid-19. Biodik, 6(2), 109-119. https://doi.org/10.22437/bio.v6i2.9759

Ulfatin, N. (2008). Jurnal Pendidikan Islam tadzikrah. Tadzkirah, 2(June), 107-151. https://doi.org/10.30596/al-ulum.v1i1.5

Vonnisye. (2020). Respon Mahasiswa Agroteknologi Terhadap Pembelajaran Daring Pada Mata Kuliah Ekologi Tanaman. IX (1).

Widodo, A., \& Nursaptini. (2004). Problematika Pembelajaran Daring dalam Perspektif Mahasiswa. Commun ACM, 47(5), 75-79.

Wirakesuma Agusta, R. (2020). Pengaruh Perkuliahan Dan Tugas Secara Daring. Jurnal Psikologi, 1(1).

Zhafira, N. H., Ertika, Y., \& Chairiyaton. (2020). Persepsi Mahasiswa Terhadap Perkuliahan Daring Sebagai Sarana Pembelajaran Selama Masa Karantina Covid-19. Jurnal Bisnis Dan Kajian Strategi Manajemen, 4, 37-45. 